\title{
Comparative Analysis on the Evaluation Method of Enterprise Profit Quality
}

\author{
Li Yao ${ }^{1, a *}$, Li Yuju ${ }^{1, b}$ \\ ${ }^{1}$ School of Economics and Management, Beijing Jiaotong University, Beijing, China
}

\begin{abstract}
As an important index to measure the operating result of enterprises, profit is the focus of accounting information users. In recent years, with the emergence of financial fraud cases in the whole world, the authenticity and reliability of accounting profits have been questioned. The users of accounting information shift their focus from the quantity to the quality of accounting profits. How to evaluate the quality of profits comprehensively and reasonably has become the focus of enterprise financial analysis. At present, the academic world has not established a unified evaluation system and method. My study summarizes and evaluates four most commonly used methods for evaluating enterprise profit quality. The study finds that all kinds of methods have their own characteristics. Each method has advantages as well as disadvantages. It is believed that the quality of profit is affected by many factors, and a variety of methods can be used for comprehensive evaluation to ensure the accuracy of the evaluation result.
\end{abstract}

\section{Introduction}

Due to the frequent occurrence of financial fraud cases, profit quality has become an important index for accounting information users to evaluate business performance. At present, scholars have not yet formed a unified opinion on the definition of profit quality, which can be summed up in three points: Point one: profit quality is the forming process of enterprise profit and the quality of profit result [1]. Point two: the narrow profit quality is expressed as the proportional relationship between accounting profit and cash flow; The generalized profit quality is the stable degree of the continuous profit development in each accounting period and the future economic growth trend of the enterprise [2]. Point three: profit quality should include two levels: quality and quantity. Quality refers to the reliability and authenticity of profit information. The income is recognized and measured in accordance with regulations, which reflects the matching degree between accounting profit and real profit. Quantity refers to the amount of profit, which is used to measure whether the enterprise has a stable free cash inflow during the accounting period [3].

To sum up the above views, high-quality profits should have the characteristics of sustainability, cash support, security, growth, profitability and so on. Scholars take different characteristics as the starting point to evaluate the quality of profit. First, sustainability. It focuses on the formation and structure of profit, especially whether it is created by the main business. Among them, scholars study the profit structure from both the internal structure, namely the harmony between core profit, investment income as well as non-operating income [4] and the matching degree between profit structure and asset structure [5]. Second, cash support. It pays attention to the matching degree of profit and cash flow, which reflects whether profit can bring corresponding cash inflow [6]. Some scholars also study the cash support through analyzing accounts receivable [7]. Third, security. It focuses on financial risk, asset risk and operating risk, reflecting whether there is hidden risk behind profit [8]. Fourth, growth. It considers about the potential for the growth of future profit [9]. Fifth, profitability. It focuses on the amount of profit, telling the efficiency of the input assets to generate profits [10]. Sixth, integrated consideration of multiple features. Design the corresponding evaluation index according to different characteristics and form the comprehensive evaluation index system of profit quality [11].

Although the dimensions and methods of evaluating profit quality are rich at present, no uniform standard has been formed. Compared to prior studies, this study contributes to the evaluation of enterprise profit quality by providing reference for the construction of a unified system from method's analyse. It is found that now there are four commonly used methods for evaluating enterprise profit: Market reaction method, Operating performance evaluation method, Analysis of account receivable and Diagnostic Method. The study summarizes and analyzes the profit quality evaluation method through comparative analysis.

a18241300@bjtu.edu.cn, b18241300@bjtu.edu.cn 


\section{COMMONLY Used Profit Quality Evaluation Methods and THEIR Characteristics}

\subsection{Market Reaction Method}

The evaluation of profit quality based on market reaction emphasizes the usefulness of profit decision making. Usefulness means that high quality profit can be recognized by market and help information users to make effective decision. ERC(Earnings Response Coefficient) is applied to measure the response of capital market investors to the earnings of listed companies. If earnings information has high value correlation, it will reflect the basic performance of enterprises. Therefore, by measuring the response degree of investors to earnings information, people can get to know the decision correlation of earnings and then judge the quality of earning. Common model used in this method is as follows: $\operatorname{Ret}_{t+1}=\alpha+\beta$ (EarningsSurpriset $)+\varepsilon_{\mathrm{t}}$. Among the model, Ret $_{t+1}$ represents the return on stock in year $\mathrm{t}+1$. $\beta$ is the earnings response coefficient. Higher $\beta$ means higher information content and higher earnings quality.

The advantages are:

- Affirming the increment of enterprise value to investors. The method studies the influence of the unit change of the stock excess market reward on the stock return rate by the regression of stock excess market returns and stock returns.

- Mature evaluation model. The beginning of the study estimates the ERC and relaxes the assumption that ERC is consistent in different company. Then, it goes further to whether the time series characteristics of accounting surplus in different company will affect ERC. Subsequently, scholars study the determinants of ERC. In the course of the study, they find that ERC obtained by the empirical test model is far lower than the theoretical value. Therefore, scholars represented by Lev [12] deeply explore the causes of this phenomenon and optimize the ERC research method.

The limitations are:

- ERC can only evaluate the usefulness of surplus information to stock investment decisions, not to other accounting information users' decisions.

- The theoretical basis of this method is the efficient market hypothesis, but the operation of capital market can not be completely efficient, and it may be difficult for the market to identify the information content of profit effectively. Therefore, it is difficult for ERC to truly reflect the profit quality of the enterprise.

- The validity of the conclusion can be affected by the measurement error of unexpected earnings, the horizontal difference in the process of income generation and other factors that influence the investor's reaction.

\subsection{Operating Performance Evaluation Method}

Operating Performance evaluation method includes direct comparison of financial indicators and comprehensive evaluation of financial indicators.

\subsubsection{Direct Comparison of Financial Indicators}

Based on the sustainability, cash support, growth, security and profitability of profit, the profit quality of enterprise is evaluated by examining the changes of corresponding financial data under each dimension. Researchers make conclusions about the profit quality through vertical or horizontal comparison. The former compares financial indices of the same enterprise during different operating periods while the latter compares the indices of the corresponding operating periods between different enterprises in the same industry.

The advantage is: It shows the difference of profit quality in different enterprises or the change of profit quality in one enterprise more intuitive through comparison.

The disadvantages are:

- Financial indices can be manipulated.

- Judging from individual or a few dimensions may lead to narrow or even wrong evaluation conclusion, which can not reflect the comprehensive characteristics of profit quality.

My study combs the existing research. And the evaluation indices with high frequency are shown in table 1.

TABLE 1. Current Commonly Used Profit Quality Evaluation Indices

\begin{tabular}{|c|c|}
\hline Dimension & Index \\
\hline \multirow[t]{4}{*}{$\begin{array}{l}\text { Sustainabi } \\
\quad \text { lity }\end{array}$} & $\begin{array}{l}\text { Core Profits/Total Profits; Operating } \\
\text { Profits/ Total Profits; Investment } \\
\text { Income/ Total Profits; Non-operating } \\
\text { Income/ Total Profits; Core } \\
\text { Profits/Investment Income }\end{array}$ \\
\hline & $\begin{array}{c}\text { Non-recurring Profit and Loss/ Net } \\
\text { Profit; Net Profit deduct Non-recurring } \\
\text { Profit and Loss/Net Profit; Profit and } \\
\text { Loss from Fair Value Changes/ Net } \\
\text { Profit } \\
\end{array}$ \\
\hline & $\begin{array}{l}\text { Operating Profit Margin; Core } \\
\text { Operating Profit Margin; Main } \\
\text { Operating Profit Margin; Non- } \\
\text { operating Profit Margin; Profit and } \\
\text { Loss from Fair value changes rate; } \\
\text { Asset Impairment Loss Rate } \\
\end{array}$ \\
\hline & $\begin{array}{l}\text { Return on Equity; Return on Operating } \\
\text { Assets; Return on Investment Assets }\end{array}$ \\
\hline \multirow[t]{2}{*}{$\begin{array}{c}\text { Cash } \\
\text { Support }\end{array}$} & $\begin{array}{c}\text { Multiple of Surplus Cash Security; } \\
\text { Operating Profit Cash Ratio; Net Profit } \\
\text { Cash Ratio; Sales Cash Ratio }\end{array}$ \\
\hline & $\begin{array}{l}\text { Cash Recovery Rate for all Assets; } \\
\text { Cash Operating Index; the Return on }\end{array}$ \\
\hline
\end{tabular}




\begin{tabular}{|c|c|}
\hline & $\begin{array}{l}\text { Investment Excluding Long-term } \\
\text { equity Transfers/Cash Receivable }\end{array}$ \\
\hline & $\begin{array}{c}\text { Operating Cash Flow per Share; } \\
\text { Income Cash Ratio }\end{array}$ \\
\hline \multirow[t]{4}{*}{ Growth } & $\begin{array}{c}\text { Growth Rate of Operating Income; } \\
\text { Growth Rate of Main Operating } \\
\text { Income }\end{array}$ \\
\hline & Net Profit Growth Rate \\
\hline & Growth Rate of Total Assets \\
\hline & $\begin{array}{c}\text { Basic EPS Growth after Non-recurring } \\
\text { Gains and Losses }\end{array}$ \\
\hline \multirow[t]{3}{*}{ Security } & Asset-liability Ratio \\
\hline & Accounts receivable / Total Profits \\
\hline & $\begin{array}{c}\text { Cash Flow Ratio; Multiple of Net Cash } \\
\text { Flow Interest Guarantee }\end{array}$ \\
\hline \multirow{2}{*}{$\begin{array}{c}\text { Profitabili } \\
\text { ty }\end{array}$} & Gross Margin; Net Sales Rate \\
\hline & $\begin{array}{l}\text { Cost-expense Profit Margin; Cost- } \\
\text { expense Net Interest Rate }\end{array}$ \\
\hline
\end{tabular}

\subsubsection{Comprehensive Evaluation of Financial Indicators}

On the basis of selecting financial indicators, a comprehensive evaluation model is constructed through relevant statistical methods to evaluate the enterprise profit quality. The comprehensive evaluation method mainly includes Factor Analysis, Cluster Analysis, Data Envelopment Analysis and Dummy Variable Method.

\subsubsection{Factor Analysis}

Considering the characteristics of profit quality mentioned above synthetically, design corresponding evaluation indices and pick up main factors. Based on the variance contribution rate of each main factor as the weight and the factor score as variable, the comprehensive evaluation index EQI of profit quality is constructed, which can be expressed by mathematical formula:EQI $=\sum \mathrm{ki} \times \mathrm{Xi}$. $\mathrm{EQI}$ provides the basis for decision makers to judge the profit quality correctly.

The virtues are:

- Reduction in the number of evaluation indicators through dimension reduction.

- It offers integrated evaluation of profit quality by calculating EQI.

The short-comes are:

- The application of the model is relatively complex and the workload is large.

- The requirement for basic data accuracy is very high, which requires high professional accomplishment.

\subsubsection{Cluster Analysis}

The basic idea is that there are different degrees of similarity between evaluation indicators. By finding out some statistics which can measure the similarity between evaluation indices and taking these statistics as the basis of classification type, the indices with large similarity degree are aggregated into a class. The closely related indexes are aggregated into a small classification unit while the estranged indexes are aggregated into a larger one. All the indexes will be aggregated into different units that form a classification system eventually. No new variables are generated during aggregation. Researchers can evaluate the profit quality of enterprises from different clustering angles coming from the system.

The advantages are:

- The evaluating process is intuitive.

- The conclusion is concise.

The disadvantage is: It is difficult to establish the classification system and determine the parameters.

\subsubsection{Data Envelopment Analysis}

Measure the profitability of the enterprise and the profit quality by constructing the linear planning model and judging the effectiveness of the work performance in decision unit. Data envelopment analysis is effective when multiple inputs of one or more organizations are in Pareto optimal state, which means that it is impossible to keep one of the inputs unchanged and reduce the input level of the other.

The virtue is: It has unique advantages in relative efficiency evaluation.

The disadvantage is: The number of decision unit limits the range of index selection which makes the evaluation conclusion limited.

\subsubsection{Dummy Variable Method}

The index is assigned to 1 or 0 according to the influence direction of the rise and fall on profit quality. And the profit quality of the enterprise is evaluated by adding the index to the total.

The advantage is: The evaluation conclusion is simple and intuitive.

The defects are:

- There is possible overlap of evaluation indicators.

- The model is too simple as it accepts the linear relationship between profit quality and evaluation index by default. And the 1 or 0 coefficient before each index is also pat. So the validity of the model needs to be verified.

\subsubsection{Analysis of Accounts Receivable}

Accounts receivable of listed companies will affect its profit quality from three aspects. First, oversized accounts receivable will reduce cash inflow and may lead to financial crisis. The scale of accounts receivable can be measured by the ratio of accounts receivable to the total assets of the enterprise. Secondly, the bad turnover of receivables judged by the turnover rate of accounts receivable will lead to a large number of bad debts. Finally, 
the excessive proportion of accounts receivable to the total income will increase the opportunity cost of the enterprise, resulting in paying too much price and reducing the profit quality. This value is actually the ratio of net accounts receivable to sales income.

The advantage is: It takes the investment in the process of profit formation into consideration, especially the capital limitation on profit.

The short-backs are:

- Accounts receivable can be manipulated, for example: recording noncollectable receivables, illegal provision for bad debts and so on.

- $\quad$ The incomplete evaluation dimension may lead to one-sided evaluation conclusion.

\subsubsection{Diagnostic Method}

The profit quality is evaluated by deep analysis of small sample events observed. Its data can be obtained from public information, company annual report, company announcement disclosure of business-related information and so on.

The advantage is: (1) Having more comprehensive and in-depth understanding of the evaluation of profit quality.

The disadvantages are:

- High requirements for comprehensiveness of financial data.

- The small number of samples may lead to errors in evaluation conclusion.

\section{Comparative Analysis of Profit Quality Evaluation Methods}

The above four types of enterprise profit quality evaluation methods have different characteristics, as shown in Table 2.

TABLE 2. Comparative Analysis on the Evaluation Methods of Enterprise Profit Quality

\begin{tabular}{|c|c|c|c|}
\hline \multicolumn{2}{|c|}{ Methods of Enterprise Profit Quality } & \multirow{2}{*}{$\begin{array}{l}\text { Advantage } \\
\text { Clear increment of } \\
\text { enterprise value; } \\
\text { Mature evaluation } \\
\text { model }\end{array}$} & \multirow[b]{2}{*}{$\begin{array}{l}\text { Limitation } \\
\text { Can't assess the usefulness } \\
\text { of surplus information for } \\
\text { other accounting } \\
\text { information users' } \\
\text { decisions (other than stock } \\
\text { investment); } \\
\text { Efficient market premise; } \\
\text { Vulnerable conclusion } \\
\text { effectiveness }\end{array}$} \\
\hline $\begin{array}{l}\text { Market Reaction } \\
\text { Method }\end{array}$ & & & \\
\hline \multirow[t]{4}{*}{$\begin{array}{l}\text { Operating } \\
\text { Performance } \\
\text { Evaluation } \\
\text { Method }\end{array}$} & $\begin{array}{l}\text { Direct } \\
\text { Comparison of } \\
\text { Financial } \\
\text { Indicators }\end{array}$ & Intuitive conclusion & $\begin{array}{l}\text { Manipulation of financial } \\
\text { indicators; } \\
\text { Can't reflect the } \\
\text { comprehensive } \\
\text { characteristics of profit } \\
\text { quality }\end{array}$ \\
\hline & $\begin{array}{l}\text { Comprehensive } \\
\text { Evaluation of } \\
\text { Financial } \\
\text { Indicators } \\
\text { Factor } \\
\text { Analysis }\end{array}$ & $\begin{array}{l}\text { Less evaluation } \\
\text { indicators; } \\
\text { Comprehensive and } \\
\text { intuitive evaluation } \\
\text { conclusion }\end{array}$ & $\begin{array}{l}\text { Complex model with great } \\
\text { workload; } \\
\text { Requirement for accuracy } \\
\text { of basic data and high } \\
\text { professional } \\
\text { accomplishment }\end{array}$ \\
\hline & $\begin{array}{l}\text { Comprehensive } \\
\text { Evaluation of } \\
\text { Financial } \\
\text { Indicators } \\
\text { Cluster } \\
\text { Analysis }\end{array}$ & $\begin{array}{l}\text { Intuitive evaluating } \\
\text { process; } \\
\text { Concise conclusion }\end{array}$ & $\begin{array}{l}\text { Difficulty in establishing } \\
\text { the evaluation system and } \\
\text { determining the parameters }\end{array}$ \\
\hline & $\begin{array}{l}\text { Comprehensive } \\
\text { Evaluation of } \\
\text { Financial } \\
\text { Indicators } \\
\text { Data } \\
\text { Envelopment } \\
\text { Analysis }\end{array}$ & $\begin{array}{l}\text { Unique advantages in } \\
\text { relative efficiency } \\
\text { evaluation }\end{array}$ & $\begin{array}{l}\text { Limitation in the scope of } \\
\text { index selection }\end{array}$ \\
\hline
\end{tabular}




\begin{tabular}{|l|l|l|l|}
\hline & $\begin{array}{l}\text { Comprehensive } \\
\text { Evaluation of } \\
\text { Financial } \\
\text { Indicators } \\
\begin{array}{l}\text { Dummy } \\
\text { Variable Method }\end{array}\end{array}$ & $\begin{array}{l}\text { Simple and intuitive } \\
\text { evaluation conclusion }\end{array}$ & $\begin{array}{l}\text { Possible overlap of } \\
\text { evaluation indicators; } \\
\text { Simple model without } \\
\text { verification }\end{array}$ \\
\hline $\begin{array}{l}\text { Analysis of } \\
\text { Receivable }\end{array}$ & $\begin{array}{l}\text { Taking the capital } \\
\text { limitation on profit into } \\
\text { consideration }\end{array}$ & $\begin{array}{l}\text { Modification in accounts } \\
\text { receivable; } \\
\text { Less dimension and one- } \\
\text { sided } \\
\text { evaluation conclusion }\end{array}$ \\
\hline $\begin{array}{l}\text { Diagnostic } \\
\text { Method }\end{array}$ & $\begin{array}{l}\text { More comprehensive } \\
\text { and in-depth } \\
\text { understanding of the } \\
\text { evaluation of profit } \\
\text { quality }\end{array}$ & $\begin{array}{l}\text { High requirement for } \\
\text { comprehensiveness of } \\
\text { financial data; } \\
\text { Small sample may cause } \\
\text { error in conclusion }\end{array}$ \\
\hline
\end{tabular}

Thus, the above methods are based on different theories and assumptions. Each of them have advantages and disadvantages. The quality of profit is affected by many factors, and a variety of methods can be used for comprehensive evaluation to ensure the accuracy of the evaluation result.

\section{Conclusion}

Factors affecting the profit quality of enterprises are complex and diverse. Among them, financial factors include: profit structure, cash flow, asset status, accounting policy and the robustness of accounting estimates. Non-financial factors include: external environment, operating leverage and financial leverage, innovation ability, corporate governance structure. Therefore, all-round factors should be taken into account in the evaluation of enterprise profit quality, especially the impact of special factors in different industries. Evaluation indicators and methods should be consistent with the industry. In addition, scholars can consider various evaluation methods at the same time so as to establish a more comprehensive profit quality evaluation system and ensure the accuracy of evaluation results. Hope my study can provide reference for the research on profit quality of enterprises.

\section{References}

1. Zhang Xinmin, Wang Xiuli,Quality characteristics of an enterprise's financial situation. Accounting Research, Vol 09, pp.35-38, 2003 (In Chinese).

2. Feng Lixia, Analysis and Reform of Performance Evaluation of Electric Power Enterprises. Electric Power Technologic Economics, Vol 03, pp.59-62, 2002(In Chinese).

3. Zhao Kesu, Peng Rui, Financial Analysis of Profit Quality of Pharmaceutical Listed Companies --
Taking Guizhou Bailing as an Example. Rural Economy and Science-Technology, Vol 07, pp.169171, 2018 (In Chinese).

4. Zhang Xinmin, Qian Aimin and Chen Deqiu, Quality of Financial Status of Listed Companies: Theoretical Framework and Evaluation Body.Management World, Vol 07, pp.152-166+204, 2019 (In Chinese).

5. Ma Guangqi, Zhang Qin, Construct the Systemic Framework of Enterprise Financial Quality Analysis from Four Dimensions. Finance and Accounting Monthly, Vol 16, pp.27-32, 2017 (In Chinese).

6. Gao Yanbin, Ruan Feifan, Evaluation of Profit Quality of Pharmaceutical Listed Companies. Friends of Accounting, Vol 22, pp.83-86, 2018 (In Chinese).

7. Li Enquan, Analysis of Enterprise Profit Quality from Accounts Receivable -- A Case Study of Western Construction. Times of Fortune, Vol 01, pp.201-203, 2020(In Chinese).

8. Jin Sijie, Analysis on Profit Quality of Yunnan Baiyao. Guangxi Quality Supervison Guide Periodical, Vol 06, pp.100-100+95, 2020 (In Chinese).

9. Wang Yannan, Financial Analysis of Profit Quality of Tianrun Dairy Industry. Shandong Textile Economy, Vol 10, pp.26-30, 2019 (In Chinese).

10. Ma Yanqi, Analysis on Profit Quality of Retail Listed Companies. China Management Informationization, Vol 11, pp.27-29, 2019 (In Chinese)

11. Tong Ying, Research on Profit Quality of Textile and Clothing Industry Based on Business Tax to Valueadded Tax. Chinese and Foreign Entrepreneurs, Vol 25,pp. 119-120, 2017 (In Chinese).

12. Lev,Baruch,and Thiagarajan,S.Ramu, "Fundamental Information Analysis", Journal of Accounting Research, Vol.31, pp.190-215, Autumn 1993. 